\title{
The damage effect on the structural capacity of school building columns due to tsunami inundation in Banda Aceh city after 16 years
}

\author{
Bunga Raihanda ${ }^{*}$ and Abdullah ${ }^{2}$ \\ ${ }^{1}$ Student of Disaster Science Department, Postgraduate Program, Universitas Syiah Kuala, \\ Jl. Hamzah Fanshuri, Darussalam, Banda Aceh, 23111, Indonesia \\ ${ }^{2}$ Department of Civil Engineering, Faculty of Engineering, Universitas Syiah Kuala, Jl. Syeh Abdurrauf No. 7, Banda Aceh, 23111, \\ Indonesia
}

\begin{abstract}
The 2004 Indian Ocean earthquake and tsunami caused catastrophic damage to buildings and infrastructure in Banda Aceh. The impact and damage depended on several factors such as the distance of the area from the coast. It was reported that in Banda Aceh, the tsunami wave inundation reached the city center and affected over a third of the population. Due to priority reasons at the time, although the structure was submerged in tsunami inundation, numerous public facilities including school buildings still in use without any proper repair. This study aims to determine the effect of column damage due to the tsunami inundation on the strength of the building. The school building of SMPN 6 Banda Aceh is selected as the case study. Seven analysis cases were carried out to simulate the degradation of the column cross-section caused by tsunami inundation. The reduction of the column cross-section was determined from 5 to $25 \%$ with increments of 5\%. The analysis results revealed that the decrease in strength has occurred from the case of $5 \%$ degradation and the vulnerability started to increase with the increase of degradation level. In the case of $25 \%$ degradation, $90 \%$ of the structure's column was at an unsafe level.
\end{abstract}

\section{Introduction}

The 2004 Indian Ocean earthquake and tsunami caused catastrophic damage to buildings and infrastructure in Banda Aceh, the capital city of the Aceh province at the northern tip of the island of Sumatera. It was reported that in Banda Aceh, the tsunami wave inundation reached the city center and affected over a third of the population [1]. It includes the deaths of over 45,000 students and 1,870 teachers and damages of 2,065 educational facilities [2].

The impact and damage depended on several factors including the distance of the area from the coast. Numerous school buildings located relatively far from the coast were not completely damaged. Due to priority reasons at the time, such buildings are still in use without any proper repair. However, the building's structure, in particular the column on the first floor, was submerged in tsunami inundation. This condition could decrease the concrete structural strength of the column, which might lead to disrupting the overall strength of the building. This condition affects one of the disaster risks factors [3], namely vulnerability (V).

Thus, to have a better understanding of the disaster risk, as one of the priority actions in the Sendai Framework for Disaster Risk Reduction (SFDRR) [4], further analysis on buildings submerged by tsunami inundation is required. Then, the risk $(\mathrm{R})$ can be reduced by lowering the value of vulnerability $(\mathrm{V})$ or increasing capacity (C).

This study aims to determine the damage level of the building structure submerged by the 2004 Indian Ocean earthquake and tsunami. The school building of SMPN 6 Banda Aceh is selected as the case study since the building was not collapsed after the earthquake and experienced the tsunami inundation.

In this study, finite element analysis was conducted to determine the effect of column damage due to the tsunami inundation on the strength and the capacity of the overall structure. The analysis results, the capacity and the strength of the column, will determine the risk level of the school building against earthquake. At the end, recommendations for repair, retrofitting, and others mitigation efforts will be proposed to reduce the risk and preventing the collapse of the building.

\section{Methodology}

\subsection{Research object}

This research is intended for a building located in the earthquake and tsunami-affected area in Banda Aceh City. The building must experience tsunami inundation without significant damage. Thus, structural rehabilitation was not carried out. Based on these

${ }^{*}$ Corresponding author: bungaraihanda@gmail.com 
conditions, the school building of SMPN 6 Banda Aceh was selected as the research object.

\subsection{Building assessment}

Field surveys were carried out at SMPN 6 Banda Aceh to collect building structure data. During the survey, direct observation was also done to assess the current condition of the building. The data obtained from the survey are as follows,

1. The location coordinate of the building is : 05³4'03" North Latitude - 95²0'37" East Longitude

2. Year of construction : 2001

3. Construction type : Reinforced concrete (RC)

4. Number of floors : 2 stories

5. Stories height : 4 meters

6. Structural dimensions :

Columns : rectangular column with $300 \times 300$ $\mathrm{mm}$ and $300 \times 400 \mathrm{~mm}$

Beams : rectangular beams with $250 \times 400 \mathrm{~mm}$ and $300 \times 500 \mathrm{~mm}$

7. Concrete property : (fc') $20,75 \mathrm{MPa}$

8. Steel strength

Longitudinal : fy $=400 \mathrm{MPa}, \mathrm{fu}=550 \mathrm{MPa}$

Transversal : fy $=240 \mathrm{MPa}, \mathrm{fu}=370 \mathrm{MPa}$

\subsection{Visual observation of column damage}

Direct observations at the SMPN 6 Banda Aceh building revealed that the concrete portion of the column which was submerged by the tsunami has cracked. Moreover, some of the concrete covers have peeled off and the exposed reinforcement was corroded. These conditions are shown in Fig. 1.

\subsection{Finite element model of the structure}

The building's structure was modeled by using the structural analysis software SAP2000. The structure was assumed to have a similar design as a reinforced concrete with open structures, in other words, frames with very minimal wall infill. Then, the structure data was input into a model in SAP2000 analysis. The building image is shown in Fig. 2 and the finite element (FE) model of the structure is shown in Fig. 3. In this building, two types of columns are used. The location of the column is illustrated in Fig. 4.

\subsection{Load condition}

In this study, the applied loading and the combination of factored loads is carried out according to Indonesian Building Code (SNI) as a reference. The load was applied depending on the analysis cases. For the case of the building at the time it was built, the general loading standard from SNI 1727-1989 [5] and the special earthquake loading standard from SNI 1726-2002 [6] were applied. For the case of the existing conditions, the loading was referred to the latest SNI, where general loading standard from SNI 1727-2020 [7] and the earthquake-specific loading from SNI 1726-2019 [8] were applied.

The earthquake loading used in the spectrum response analysis was in the form of spectral plots. The earthquakes loading based on the building code of SNI 1726-2002 and SNI 1726-2019 are shown in Fig. 5 and Fig. 6, respectively.

\subsection{Tsunami inundation height}

According to the research conducted by Iemura et al (2008) [9] in building the Tsunami Height Memorial Poles in Banda Aceh and Aceh Besar, the tsunami inundation at SMPN 6 Banda Aceh is $1.80 \mathrm{~m}$ high with a distance to the coast of about $3.85 \mathrm{Km}$. The tsunami memorial pole at SMPN 6 Banda Aceh is shown in Fig. 7.

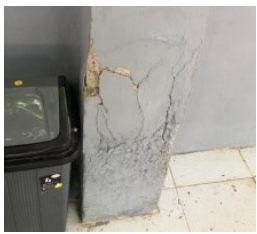

(a) Column cracks

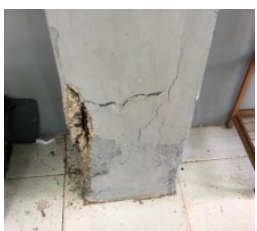

(b) Concrete cover loss

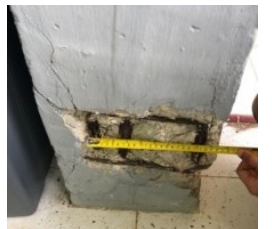

(c) Corroded reinforcement
Fig 1. Column conditions

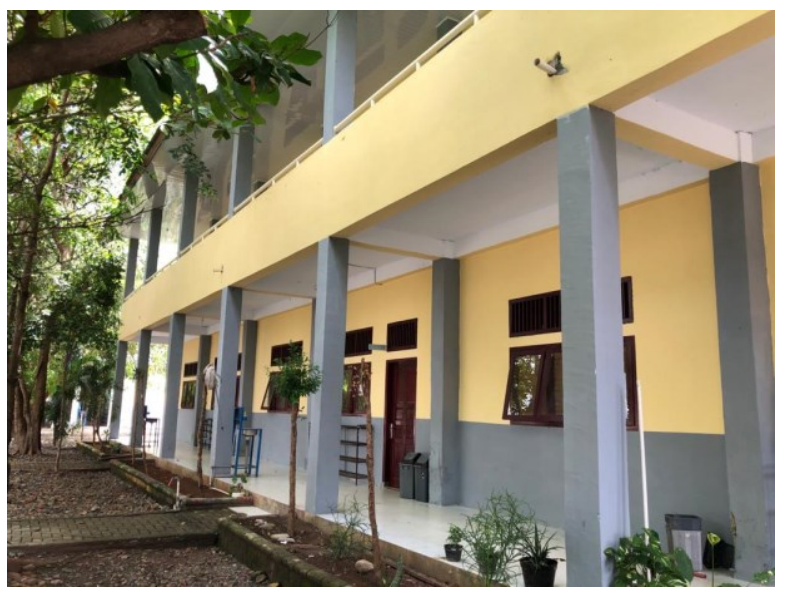

Fig 2. School building

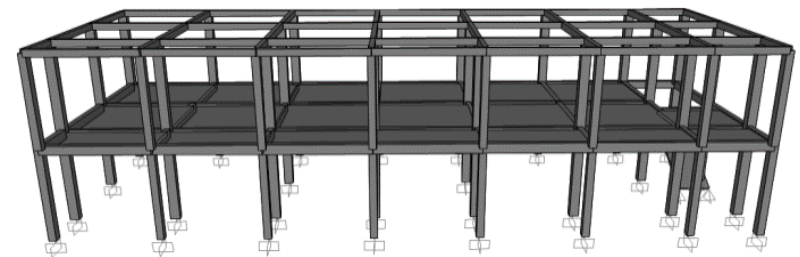

Fig 3. FE 3D model of the structure 


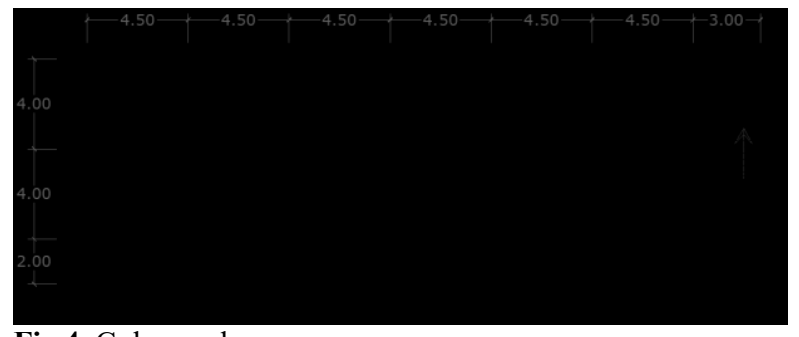

Fig 4. Column plan

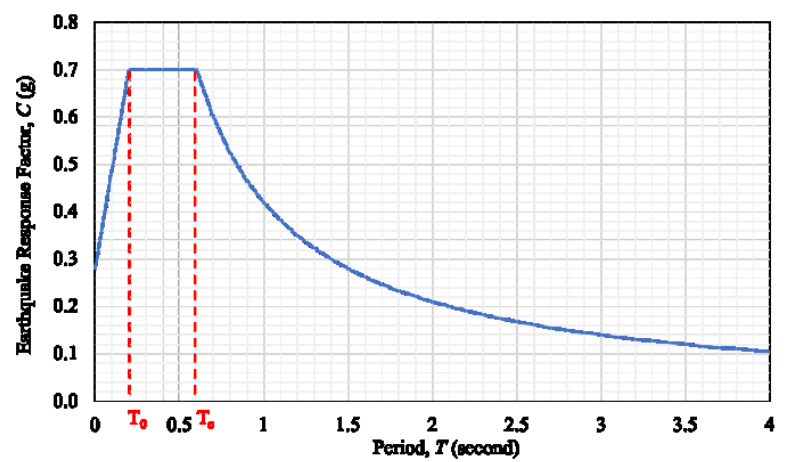

Fig 5. Spectrum of SNI 1726-2002

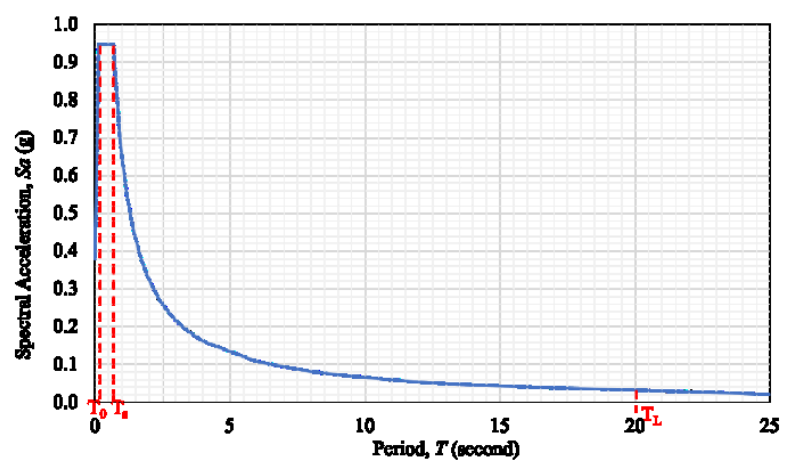

Fig 6. Spectrum of SNI 1726-2019

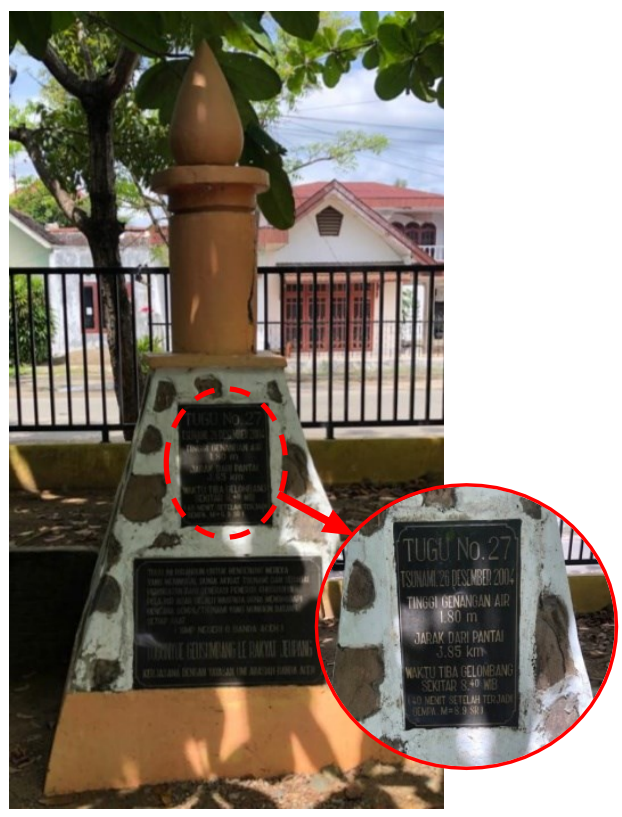

Fig 7. Tsunami memorial pole in SMPN 6 Banda Aceh

\subsection{Analysis cases}

In actual condition, the column was built following the cross-section of the design size. Then, since the column was submerged by tsunami inundation and was not repaired, the degradation of column section, cracking, and cover loss is unavoidable. The column cross-section sizes gradually decreased and lead the reinforcement to corrode.

To simulate the effect of degradation of the column cross-section caused by tsunami inundation, seven scenario of analysis cases were carried out as illustrated in Fig. 8. The degradation of the column size was carried out sequentially to evaluate the capacity of the building structure. The reduction of the column cross-section was determined from 5 to $25 \%$ with increments of $5 \%$. The degradation percentage of column cross-section were applied on each side of the width and depth.

Case 1 was the condition of the column cross-section following the design size and the applied earthquake loading from SNI 1726-2002 was used. Case 2 was the condition of the column cross-section following the
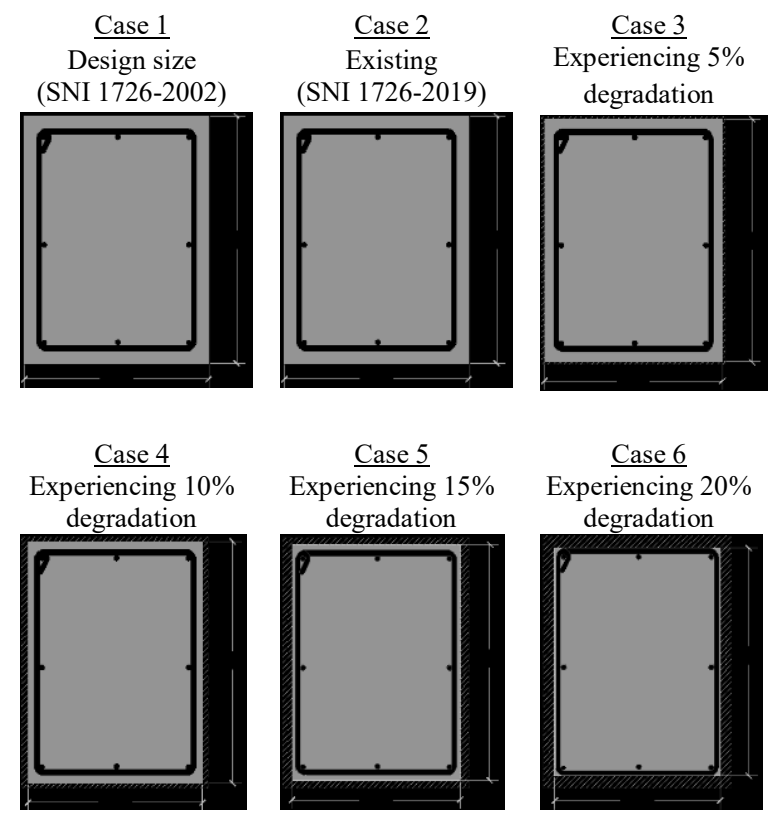

Case 7

Experiencing $25 \%$ degradation

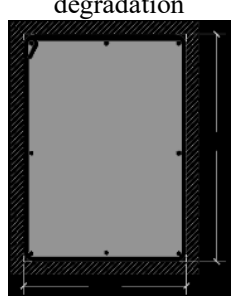

Fig 8. Column degradation included in the analysis

design size but the special earthquake loading from SNI 1726-2019 was used. Case 3 to 6 was analyzed by reducing the cross-sectional size of the column due to concrete cover deterioration caused by tsunami inundation. In case 7 the analysis was carried out with 
complete loss of the concrete cover, and the degradation of the size of the reinforcement due to corrosion.

Case 7 was carried out to simulate the above conditions. In this case, the column was experienced complete concrete cover loss and the reinforcement started to corrode. Thus, it was required to reduce the cross-sectional areas of the reinforcement in the analysis. The reduction in the reinforcement crosssection due to corrosion of $5.64 \mu \mathrm{m} / \mathrm{yr}$ was used in the analysis referred to the research conducted by Al-Hadi (2016) [10].

\section{Result and discussion}

\subsection{Initial structural capacity}

Finite element (FE) analysis was carried out by using SAP2000 software to obtain the structural capacity of the building. Initially, the analysis of Case 1 and Case 2 was carried out to ensure if the structural capacity of the building meets the former and latest Indonesia Building Code (SNI). The visualization of the analysis results of Case 1 and Case 2 are shown in Fig. 9 and Fig. 10, respectively. An indicator is provided in each figure. The grey color indicates the safest condition and the red color indicates the most severe conditions.

In Case 1, the analysis result shows that most of the columns are in a light blue color, indicating that the structure is safe. In Case 2, where the applied earthquake load was updated to the latest SNI, the analysis result shows more columns had turned green, indicating that the capacity of the column was decreased, in other words, the vulnerability level of the column was increased. However, the structure is still within the safe level. According to the results, it can be concluded that differences in structural capacity were observed by updating the earthquake loading standard.

\subsection{Analysis results of degradation section}

Degradation of concrete columns due to tsunami inundation was simulated by reducing the column crosssection from 5 to $25 \%$ with increments of $5 \%$, which represented as Case 3 to Case 7. The visualization of the analysis results for each case is shown in Fig. 11 to Fig. 15 , respectively. An indicator is provided in each figure. The grey color indicates the safest condition and the red color indicates the most severe conditions.

Comparing the analysis results of Case 1 to Case 7, it can be observed that the structural capacity is gradually decreased along with the degradation of the column cross-section. In other words, as the capacity of the structure is decreased, the vulnerability level of the structure is increased. The comparison of the number of vulnerability columns of each analysis case is listed in Table 1.

Start from Case 3, the red columns were observed. It indicates that the strength of the column was decreased and become incapable to bear the applied loads. According to the analysis results, when $10 \%$ of column cross-section has degraded, as in Case 4, it can be concluded that the risk of structural building collapse has increased. When the column cross-section has degraded for $15-25 \%$ as in Case $5-7$, the structure is no longer safe and will fail because above $30 \%$ of main column of the structure is no longer able bearing the weight of the structure. Deteriorated column caused structural failure where the entire building will collapse because the column is main structural component that play important role bearing the weight of building.

Table 1. Comparison of column vulnerability due to degradation

\begin{tabular}{|l|c|c|c|c|c|c|}
\hline \multirow{2}{*}{$\begin{array}{c}\text { Case } \\
\text { Number }\end{array}$} & \multicolumn{2}{|c|}{$\begin{array}{c}\text { Number } \\
\text { of }\end{array}$} & \multicolumn{2}{c|}{$\begin{array}{c}\text { Number } \\
\text { of } \\
\text { Vulnerabe } \\
\text { Columns }\end{array}$} & \multicolumn{2}{c|}{$\begin{array}{c}\text { Percentage } \\
\text { oulnerable } \\
\text { Columns } \\
\text { (\%) }\end{array}$} \\
\cline { 2 - 8 } & K1 & K2 & K1 & K2 & K1 & K2 \\
\hline Case 1 & 8 & 21 & 0 & 0 & 0 & 0 \\
\hline Case 2 & 8 & 21 & 0 & 0 & 0 & 0 \\
\hline Case 3 & 8 & 21 & 0 & 1 & 0 & 4.8 \\
\hline Case 4 & 8 & 21 & 0 & 4 & 0 & 19.1 \\
\hline Case 5 & 8 & 21 & 0 & 9 & 0 & 42.9 \\
\hline Case 6 & 8 & 21 & 3 & 17 & 37.5 & 80.9 \\
\hline Case 7 & 8 & 21 & 4 & 19 & 50.0 & 90.5 \\
\hline
\end{tabular}

K1 = column 300x300 mm, K2 = column 300x400 mm.

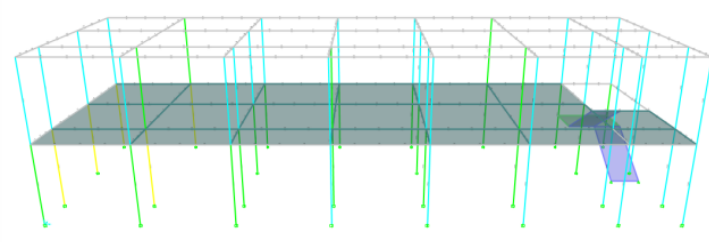

Fig 9. Case 1 - Structural capacity check visualization

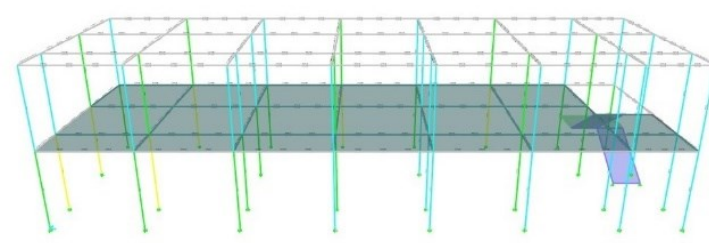

Fig 10. Case 2 - Structural capacity check visualization

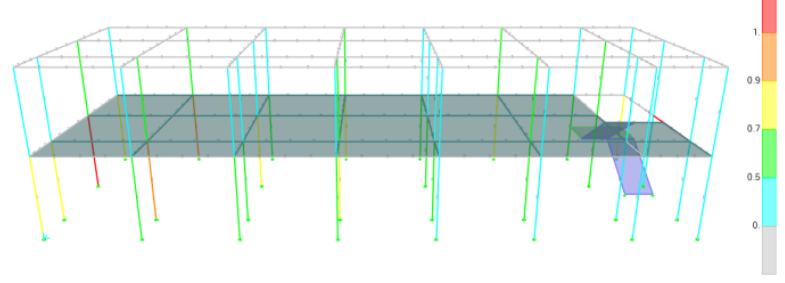

Fig 11. Case 3 - Structural capacity check visualization 


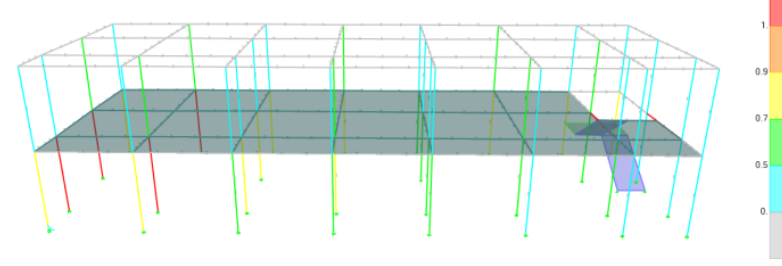

Fig 12. Case 4 - Structural capacity check visualization

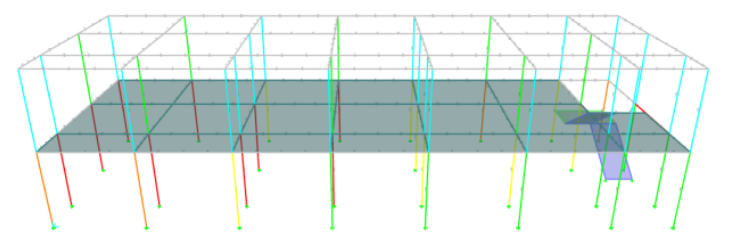

Fig 13. Case 5 - Structural capacity check visualization

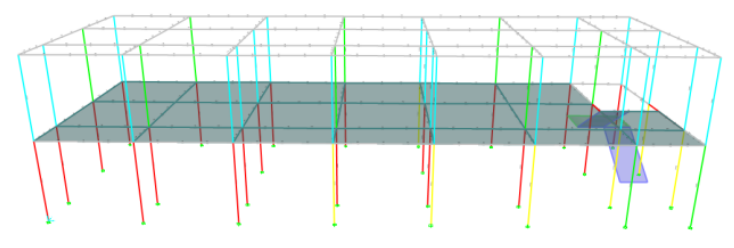

Fig 14. Case 6 - Structural capacity check visualization

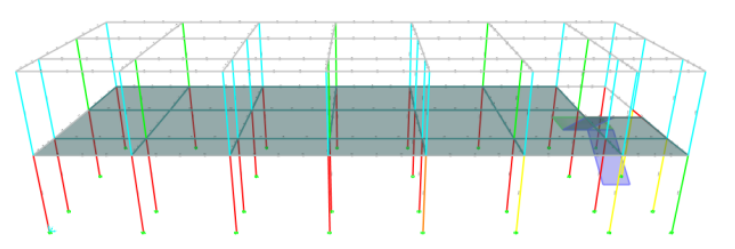

Fig 15. Case 7 - Structural capacity check visualization

\subsection{Retrofitting and recommendations}

During the field survey and direct observation, it was found that most of the column on the first floor, which experienced 1.8 meter high of tsunami inundation, was degraded. Associating direct observation data and Finite Element (FE) analysis results, the columns of SMPN 6 Banda Aceh structure is classified as heavy damage.

Such conditions of the school buildings are certainly hazardous to the building users, includes students and teachers who are included in the vulnerable group on the disaster risk index. In addition, recognizing that schoolage children spend majority of their day hours at school, school buildings need to be protected from any vulnerabilities. Moreover, resilient schools are an effective means for disseminating disaster risk reduction awareness in the communities and can provide emergency shelters immediately after disasters.

As the structural mitigation efforts, it is recommended to evaluate the condition and the function of the school buildings, as well as other public facilities. Particularly, those submerged to the tsunami inundation and unrepaired yet, since similar damage might have occurred. The capacity of the existing structure should be enhanced by applying retrofitting methods.

One of retrofitting methods for flexural columns is by adding reinforcements. This method is effectively applied to vulnerable columns so that it can increase column capacity and reduce direct shear failure.

The other retrofitting method is column jacketing. Jacketing is a method of structural retrofitting and strengthening aims to increase or restore the structural capacity of existing structures by providing wrapping sheets of additional material around the existing member. This additional material can be of several types such as concrete, steel, FRP, and composites.

In the end as the non-structural mitigation strategies, it is expected that the local government and stakeholders could develop strategies and policies, such as regular assessments to evaluate the damaged school buildings, to reduce disaster risk by knowing the vulnerability of school building earlier.

\section{Conclusion}

The analysis result shows that most of the columns are in a light blue color at the design condition, indicating that the structure was safe. Then, for at the existing building condition, where the applied earthquake load was updated to the latest SNI (Indonesia building code), the analysis result shows more columns had turned green, indicating that the capacity of the column was decreased, in other words, the vulnerability level of the column has increased.

The degradation of concrete columns results for each case shows that the structural capacity is gradually decreased along with the degradation of the column cross-section. The capacity of the structure is decreased, and the vulnerability level of the structure is increased. The first degradation scenario, in Case 3, already shows that the strength of the column was decreased and become incapable to bear the applied loads. The worst condition starts in case 5 , where $30 \%$ of the main column of the structure became unable to bear the weight of the structure. In other words, the structure is no longer safe and failure might happen at this point. As the main structural component that play important role in bearing the weight of the structure, deteriorated column caused the structural failure and the entire building might collapse.

According to the analysis results, the conditions of the school buildings are certainly hazardous to the building users, including students and teachers who are included in the vulnerable group on the disaster risk index. Therefore, structural and non-structural mitigation strategies should be done especially by the local government to reduce hazards and to increase 
capacity of the building structures to minimize the disaster risk.

Acknowledgement. This research was conducted independently without external funding. The authors are grateful to Ms. Cut Atika Putri and Mr. Rifqi Irvansyah for the assistance provided in this study.

\section{References}

1. Ghobarah, A., Saatcioglu, M. and Nistor, I. 2006. The impact of the 26 December 2004 earthquake and tsunami on structures and infrastructure. Engineering structures, 28(2), pp.312-326.

2. Bappenas and International Community. 2006. Indonesia: Preliminary Damage and Loss Assesment; The December 26, 2004 Natural Disaster. Bappenas: Indonesia.

3. Adiyoso, W. 2018. Manajemen Bencana: Pengantar dan Isu-Isu Strategis. Bumi Aksara.

4. The United Nation Office for Disaster Risk Reduction (UNDRR). 2015. Sendai Framework for Disaster Risk Reduction 2015-2030. The United Nation Office for Disaster Risk Reduction: Geneva, Switzerland.

5. Badan Standarisasi Nasional. 1989. Standar Nasional Indonesia 1727-1989: Tata Cara Perencanaan Pembebanan untuk Rumah dan Gedung. Badan Standarisasi Nasional: Jakarta.

6. Badan Standarisasi Nasional. 2002. Standar Nasional Indonesia 1726-2019: Tata Cara Perencanaan Ketahanan Gempa untuk Struktur Bangunan Gedung dan Non Gedung. Badan Standarisasi Nasional: Jakarta.

7. Badan Standarisasi Nasional. 2019. Standar Nasional Indonesia 1726-2019: Tata Cara Perencanaan Ketahanan Gempa untuk Struktur Bangunan Gedung dan Non Gedung. Badan Standarisasi Nasional: Jakarta.

8. Badan Standarisasi Nasional. 2020. Standar Nasional Indonesia 1727-2020: Beban Desain Minimum dan Kriteria Terkait untuk Perancangan Bangunan Gedung dan Struktur Lain, Badan Standarisasi Nasional: Jakarta.

9. Iemura, H., Pradono, M. H., Sugimoto, M., Takahashi, Y., dan Husen, A. 2012. Tsunami Height Memorial Poles In Banda Aceh And Recommendations For Disaster Prevention, Proceedings of the International Symposium on Engineering Lessons Learned from the 2011 Great East Japan Earthquake, Tokyo, Japan, March 1-4.

10. Al Hadi, H. 2016. Aplikasi Metode Linear Polarization Resistance Untuk Mengukur Laju Korosi Infrastruktur Pasca Sepuluh Tahun Tsunami 2004. ETD Unsyiah. 